\title{
Market Analysis and Affirmation Factors of the Northern Sea Route
}

\author{
Tanja Poletan Jugovića , Dražen Žgaljića, Katarina Balićb
}

Maritime transport routes, or corridors, imply specific courses of movement for people and goods (freight) on maritime routes and bring multiple benefits to the area through which they pass. The action and influence frame of a single route in the international transport flow is defined by an increasingly pronounced international competition at the regional and/or global transport market. Considering that the competitiveness of a transport route represents the fundamental factor of its valorization in the transport services market, the question of what defines and conditions the competitiveness mentioned above should be considered. This paper analyzes the competitiveness of the Northern Sea Route as a shorter maritime route between Asia and Europe. Under the new climate conditions in which, over the past few years in September, the Northern Sea Route course is completely ice-free, the indicated route represents a sort of competition to the alternative route through the Suez Canal. Taking into account that the competitiveness of a transport route is conditioned by market determination as well as by the

\section{KEY WORDS}

$\sim$ Northern Sea Route

$\sim$ Transport supply

$\sim$ Demand

$\sim$ Competitive environment quantity of freight flow through the transport route, the main research aim of this paper is to analyze the current and potential transport supply and demand as well as the Northern Sea Route's competitive environment in order to assess, in this regard its valorization and affirmation possibilities.

\section{INTRODUCTION}

Maritime transport is the main transport mode in the structure of world cargo transport and initiator of commercial exchange in the world. It takes place in maritime transport routes, which connect large industrial, transport, and commercial hubs and their ports in which maritime freight flows are formed. Nowadays, the intensity and quantity of maritime freight flows have become a benchmark for transport effectiveness and usefulness, for inclusion in the international labor division as well as a standard for the level of economic development of a country. Accordingly, along with the existing transport routes, new transport courses affirm themselves in this competitive transport market and with their geo-traffic position they compete with the existing transport routes. As a result, this paper analyses the potential and the affirmation opportunities of the Northern Sea Route.

Under the influence of climate change the amount of sea ice in the Arctic has drastically decreased, thus opening opportunities for international maritime navigation in this area, primarily through the Northern Sea Route as the shorter maritime route between Asia and Europe in comparison to alternative routes through the Suez Canal. The fact that in the past few years in September the Northern Sea Route has been completely ice-free and that this condition allows seasonal navigation for commercial ships opens the potential and opportunity for affirmation of the indicated route as well as the opportunity for affirmation of new commercial shipping lines through the route. 
In addition to the new global climate changes which already exist in the Arctic area, the valorization of the Northern Sea Route in the transport services market is conditioned on multiple geo-transport, political, ecological, and socio-economic determinants, which require an in-depth analysis and discussion.

While respecting all the influence of the above mentioned factors, this paper will focus on the market definition analysis of the Northern Sea Route, which is primarily conditioned by three market components: supply-demand and environment. In fact, based on the current estimates, navigation through the Northern Sea Route would largely facilitate international commerce. Among other things, limitations in fuel quantity which are entering into force in the entire world will lead to "transport giants" trying to reduce costs and use shorter and more efficient maritime routes. In line with this, the Northern Sea Route could potentially represent a new alternative to the route through the Suez Canal.

With the aim to determine the above mentioned potentials and affirmation factors of the Northern Sea Route, this paper analyzes the transport supply, the transport demand and the competitive transport environment as well as the new transport routes and reference ports along the Northern Sea Route, which will largely shape the position of the indicated maritime route in a competitive maritime market.

\section{NORTHERN SEA ROUTE TRANSPORT SUPPLY AND DEMAND}

Generally speaking, the transport route offer may include different transport branches, traffic hubs, port terminals, land terminals as well as other elements and participants to the production of transport services on the transport route (Poletan Jugović T., 2014).

Transport supply is relevant on maritime routes in order for a maritime route to survive. This is reflected in the intensity, structure and quality of commercial shipping lines offered by ship owners as well as in the capacity of the infra- and superstructure and in the quality of services in ports as significant transshipment and logistic-distribution centers, within maritime routes.

In the Northern Sea Route area, ports are being constructed together with the accompanying facilities such as a rescue service, a maintenance center, an airport, and a railway. The above mentioned represents an investment for the future as it reduces risks and increases the attractiveness of commercial transport operators.

In their intention to diversify transport courses towards Europe even the great powers such as China and Japan seek to connect the Chinese project "One Belt, One Road" with the Northern Sea Route. Based on a new national program for the socio-economic development of the Arctic area, even the powerful Russia is interested and plans to invest in the infrastructure of the Northern Sea Route for about half a billion euros. According to certain forecasts, it is expected that by 2029 the freight transport through the Northern Sea Route will increase 11 times. Furthermore, it is expected that by 2035 Russia, with its largest icebreaker fleet in the world will allow eight more icebreakers to navigate through the Northern Sea Route (Express.hr, 2019).

According to the data on transit traffic through the Northern Sea Route, an increasing number of countries is showing a potential interest for affirmation and investments. The Danish Company Maersk, for instance, had already tested the possibility of using the Northern Sea Route course as an alternative route to the course from Asia to Europe through the Suez Canal.

Maritime transport via the Northern Sea Route is the only delivery route for natural resources originating in the remote Arctic regions where there are no pipelines, roadways, or railway infrastructure. Cargoes for export from the Arctic will remain the driving force for the development of shipping on the Northern Sea Route. In the future, oil, gas (LNG), coal, various ores and minerals, fish and timber products will continue to be the main cargoes to be transported from the Russian Arctic to markets in Northeastern Europe and Northeastern Asia. (Centre for High North Logistic, 2019).

As far as the main freights on the indicated route are concerned, a particular emphasis should be put on energy resources such as LNG, oil, coal, but even metal. With regard to this, launching of the complex "Jamal LNG" in December 2017 in the Northern route when five LNG consignments departed from the Russian port of Sabetta was of great significance for the traffic growth. Today China cooperates actively with South Korea, which builds ice tankers and is ready for the construction of icebreakers, while Russia is building a huge shipyard called "Star" in a littoral zone in the Pacific, where classic vessels for navigation in the Northern Sea Route will be constructed (Babić N., 2018).

In the context of analysis of the existing supply and demand, Table 1 and Figure 1 display the structure of voyages through the Northern Sea Route, according to the type of vessels which navigated through the above mentioned route in 2017.

From Table 1 and Figure 1 it may be noticed that in the structure of voyages through the Northern Sea Route the most significant presence of voyages is realized by vessels for the transportation of general freight and vessel for the transportation of oil, i.e. tank ships. Specifically, in the total structure of vessels traveling through the above-mentioned route in 2017, general cargo carriers (29\%) and tankers (18\%) dominate. In the total structure of voyages through the Northern Sea Route, from a total of 1,908 voyages within freight shipping lines, the largest number of voyages is realized by general cargo carriers (30\%), followed by tankers (34\%), and tug and icebreaker (5\%). 
Table 1.

Structure of voyages through the Northern Sea Route according to the type of vessel (Centre for High North Logistic, 2018).

\begin{tabular}{|c|c|c|}
\hline Type of vessels & Vessels & Voyages \\
\hline Barge & 0 & 0 \\
\hline Boat & 1 & 2 \\
\hline Bulk & 9 & 48 \\
\hline Container & 6 & 103 \\
\hline Crane & 1 & 7 \\
\hline Dive & 1 & 2 \\
\hline Dredger & 4 & 10 \\
\hline Drilling & 1 & 2 \\
\hline Fishing & 11 & 38 \\
\hline General cargo & 83 & 570 \\
\hline Heavy load & 19 & 46 \\
\hline Icebreaker & 16 & 105 \\
\hline LNG tanker & 4 & 13 \\
\hline Pipe burying & 0 & 0 \\
\hline Pallet & 2 & 6 \\
\hline Passenger & 3 & 17 \\
\hline Pilot & 1 & 4 \\
\hline Reefer & 4 & 9 \\
\hline Research & 20 & 87 \\
\hline SAR & 6 & 22 \\
\hline Supply & 10 & 57 \\
\hline Tanker & 51 & 648 \\
\hline Tug & 28 & 105 \\
\hline Yacht & 2 & 7 \\
\hline Auxiliary vessel & 0 & 0 \\
\hline Hopper & 0 & 0 \\
\hline Total number & 283 & 1,908 \\
\hline
\end{tabular}

Transport demand is based on the demands of service users, i.e. market demands. The condition of transport service demand can be analyzed, evaluated, and expressed by the intensity of cargo flows with respect to the orientation, i.e., the main directions of cargo flows (Poletan Jugović T., 2014). There are three different relationships between the supply of transport capacity that provides services and transport demands: a shortage in supply of transport capacity in relation to the transport demand, excess of supply relative to demand, and coordinated

\section{Voyage made by different types of vessels} in 2017

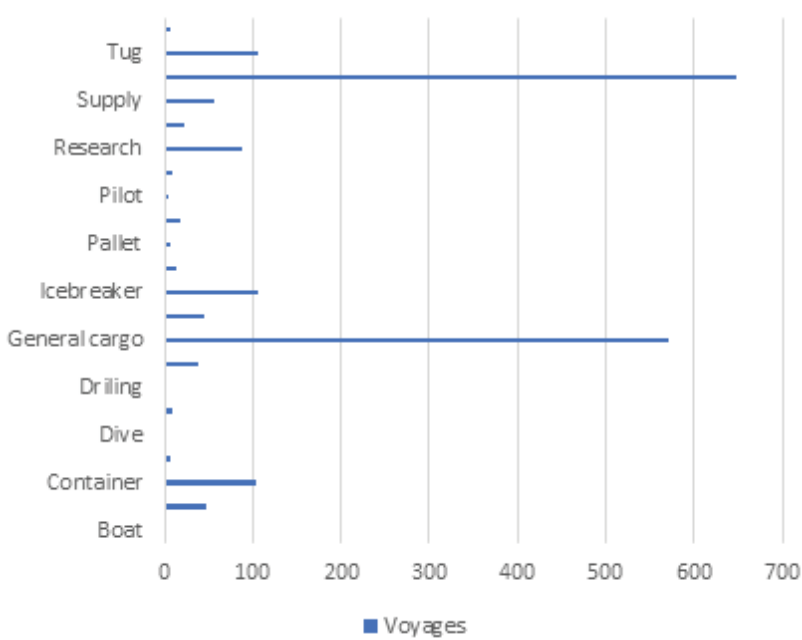

Figure 1.

Structure of voyages through the Northern Sea Route according to the type of vessel (Centre for High North Logistic, 2018).

relationship between supply and demand. The task of the port traffic forecasting is to determine the quantity, type and structure of the cargo that will be moved through the port in the following period (Jugović A. et al., 2010.). Accordingly, transport flows of general and oil cargoes are currently the dominant cargo types in the Northern Sea Route. It should be noted that Russia uses the Northern Sea Route the most, valorizing the Arctic region for its military and economic purposes and as a source of natural resources.

An evaluation has been developed that about $13 \%$ of the world's undiscovered conventional oil reserves are situated in the Arctic and $30 \%$ of undiscovered gas sources, which justified the fact that the Arctic region as a source of natural resources will continue to be interesting (Babić N., 2018). With this in mind and in relation to this route, even in the future we can expect the presence and the potential intensification of this type of freight flows.

As a testimonial of the current and, thus, even potentially predictable interest, there are data regarding the structure of vessels (according to the flag state), which navigated through the Northern Sea Route in 2018.

Based on the data displayed in Figure 2, it may be noticed that in the winter period (from January to June) 2018 even 75\% of vessels which navigated through the Northern Sea Route were vessels under the Russian flag. 


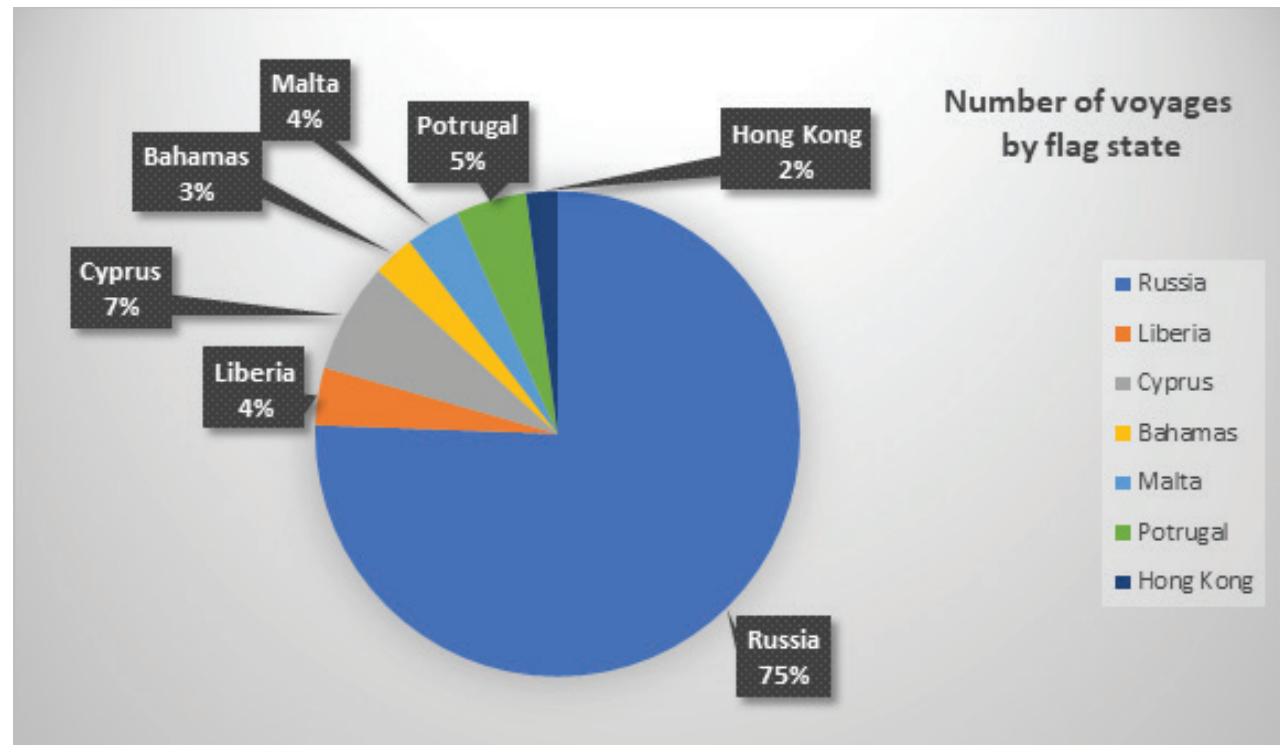

Figure 2.

Vessel structure in the Northern Sea Route according to the flag state, in the period from January to June 2018 (Centre for High North Logistic, 2018).

\section{THE NORTHERN SEA ROUTE'S COMPETITIVE TRANSPORT ENVIRONMENT}

Maritime transport is essential to the world's economy as over $90 \%$ of the world's trade is carried by sea (IMO, 2019), and the quantities that currently pass through the Northern maritime route cannot be compared with the quantities passing through the Suez Canal. However, according to some assessments, it is considered that the Northern maritime route will compete with the Suez Canal route from the Far East to the Pacific, through the Suez Canal towards Europe and the American continent.

Based on the available transport data, freight for the amount of 194 thousand tons has been evidenced through the Northern Sea Route in 2017. At the same time, more than a billion tons of freight, which is 5,000 times more, have passed through the Suez Canal. Taking this into account, it should be emphasized that the Russian goal is to increase the flow of freight passing through the Northern Sea Route to 80 million tons ("Pomorac", 2018).

In the following table, a comparative analysis of space and time components of the voyage through the Suez Canal and the Northern Sea Route is displayed. Data in the table are related to the starting points of Murmansk and to a speed of 14 knots, which is a constant.

Table 2.

Analysis of the spatial and time components of the voyage through the Suez Canal and the Northern Sea Route (Arctic Bulk, 2013).

\section{Voyage through the Suez Canal}

\section{Voyage through the Northern Sea route}

\section{Difference} between the voyages in days

\begin{tabular}{lccccccc}
\hline $\begin{array}{l}\text { Starting point/ } \\
\text { Destination }\end{array}$ & Distance & Speed in knots & No. of days & Distance & Speed in knots & No. of days \\
\hline $\begin{array}{l}\text { Murmansk-Shanghai/ } \\
\text { China }\end{array}$ & 12,050 & 14 & 37 & 6,500 & 14 & 19 & 18 \\
\hline $\begin{array}{l}\text { Murmansk-Busan/ } \\
\text { Korea }\end{array}$ & 12,400 & 14 & 38 & 6,050 & 14 & 18 & 20 \\
\hline $\begin{array}{l}\text { Murmansk- } \\
\text { Yokohama/ Japan }\end{array}$ & 12,730 & 14 & 39 & 5,750 & 14 & 17 & 22 \\
\hline
\end{tabular}


The above mentioned shows that travelling through the Northern Sea Route can significantly shorten the traditional route to Europe through the Suez Canal by almost 20 days and that the Northern Sea Route is half shorter in comparison to a voyage through the Suez Canal, which implies a definite advantage of the Northern Sea Route in the context of the voyage time and cost component, which consequently suggests even the economic effects of the voyage. According to some evaluations, foreign ship owners can speed up the consignment through the Northern Route, thus insuring an economic effect of even 500 thousand dollars with each consignment ("Pomorac", 2018). This demonstrates the sustainability of the Northern Sea Route in comparison to an alternative maritime route through the Suez Canal, presuming adequate climate conditions and the reduction of the quantity of ice, not only during the summer, but during the entire year, as it may be seen in the following figure.

The analysis of the realized voyages through the Northern Sea Route in 2016 and 2017 suggests that 69\%, i.e. the biggest share of the voyages, was realized in the winter months (from December to May 2017), while only 31\% of the voyages took place during the summer months (from June to November 2017). Based on the data for 2016 and 2017, the Northern Sea Route is mostly trafficked in September (Centre for High North Logistic, 2018). The reason for this lies in the fact that precisely in that period the smallest quantity of ice is present on the above mentioned route, which alludes to the influence of ice as a crucial climate factor in time distribution when travelling on this route.

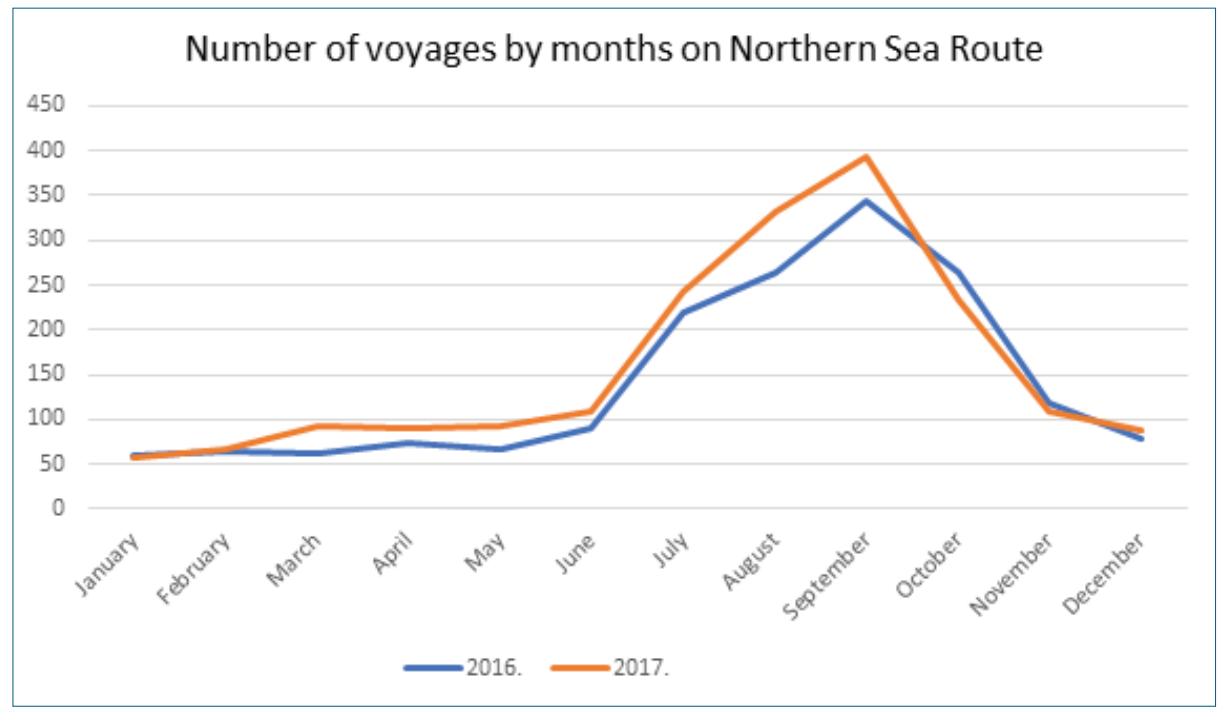

Figure 3.

Time difference in Northern Sea Route voyages for 2016 and 2017 by months (Centre for High North Logistic, 2018).

Currently, the Northern Sea Route is navigable only for four months a year; however, climate change or, more precisely, the reduction in the quantity of ice will contribute to the development and navigability of this route. Until then, it will be necessary to build expensive icebreakers, which requires additional costs. In terms of cost, the route today is still less favorable due to the need for ice-classed ships and ice-breaker assistance, non-regularity of the liner services, slower sailing speeds, navigation difficulties and Russian transit fees (Rodrique J.P., 2017).

The traffic environment within which the Northern Sea Route exists shows traffic routes, or starting-up destination areas which use the indicated route in the function of international maritime commerce and services, with the above mentioned dominant types of goods (freight).

According to the maritime freight directions and number of voyages though the Northern Sea Route during 2017 (a total of
1,908 voyages), the following traffic directions can be structured: (Centre for High North Logistic, 2018).

- traffic directions from European ports, including part of the routes towards European ports through the Suez Canal (54 voyages)

- $\quad$ traffic directions within the areas of Western (European) Russia (537 voyages)

- traffic directions from/to ports of Northern Russia towards Eastern (European) ports and Western (Russian and Asian) ports (657 voyages)

- $\quad$ traffic directions from/to (between) Northern Russian ports (591 voyages)

- traffic directions through the Northern Sea Route (for Europe, Asia) (27 voyages)

- $\quad$ traffic directions from Eastern Russia (30 voyages)

- $\quad$ traffic directions from Asian ports (12 voyages). 


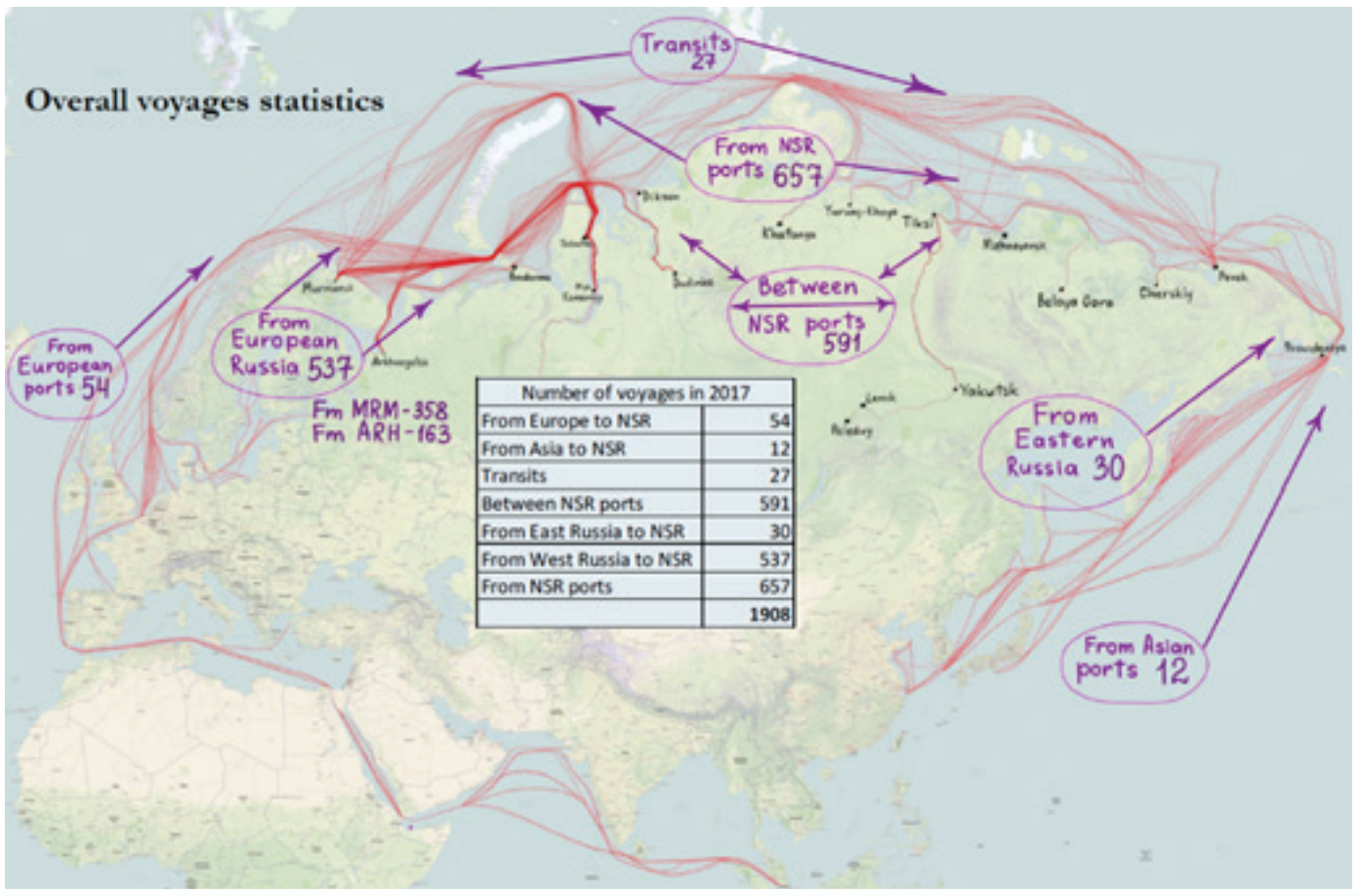

Figure 4.

Traffic directions of freight flows (voyages) through the Northern Sea Route in 2017 (Centre for High North Logistic, 2018).

According to their initial destination areas and ports, the indicated routes differentiate based on the traffic intensity, i.e. the number of voyages, as previously mentioned. It can, therefore, be concluded that the most intensive traffic route is the one from/to the Northern Russian ports towards the Eastern (European) ports and Western (Russian and Asian) ports. With regard to the total number of voyages in 2017 , this route has registered $34 \%$ of the voyages.

Immediately after this route, and based on intensity, i.e. on the number of voyages, we can find the routes between Russian ports with a $30 \%$ share, and the routes within the area of Western (European) Russia with a $28 \%$ share in all voyages.

Routes from the European ports, including part of the routes towards the European ports through the Suez Canal, have also been actualized, which suggests that a certain amount of freight circulating through the Northern Sea Route travels from the Suez Canal, a route with which the Northern Sea Route can potentially compete. Part of the traffic routes that pass through the Northern Sea Route represent a transit in the need of Asian and European ports. The Northern Sea Route can therefore be defined as a competitive market of crucial interest as the most intense traffic route in the global maritime transport as far as the relation Asia-Suez Canal-Europe is concerned.

\section{INFLUENCE OF THE AFFIRMATION OF THE NORTHERN SEA ROUTE ON THE WORLD'S MARITIME ROUTE}

Along with the intensification of the energy and mineral resources in the Northern region, an efficient alternative transport solution, between Europe and the Far East, will become of utmost importance. This will result in the formation and consolidation of potentially new freight flows that will significantly affect the intensity of the traffic and the development of hub ports on the analyzed route, as well as the general frame of the world's maritime transport. Considering the above mentioned and along the lines of the main aim of this research, what follows is a statistical analysis of the effects of the Northern Sea Route's affirmation in the context of consolidation of the new transport routes and freight flows, as well as in the context of affirmation of the sea ports, that will be in function and of service to the latter.

\subsection{Affirmation of the New Transport Routes and Freight Flows}

At the beginning of 2018, China became Russia's main partner in the common use of the Northern Sea Route. China intends to support and work on the affirmation of the Northern 
Sea Route, i.e. the so-called Polar Silk Road in the Arctic. It participates in the study of navigation modes, i.e. of hydrographic work, but also in the scientific research in the Arctic. The Russian efforts as well as their adoption of special laws in the Northern Sea Route have inspired China to also add among its strategic projects the Polar Silk Road (Babić N., 2018).

The initiative "Belt \& Road" is a Chinese proposal, whose goal is to promote a peaceful cooperation and a common development of the world. The cooperation "Belt \& Road" is a framework in which all countries, smaller or larger, richer or poorer, can participate on equal basis. This cooperation is public, transparent, open, and it brings positive energy, peace and development to the world (Koboević Ž. et al, 2018). The initiative Belt \& Road is very significant because infrastructure has historically tended to be something that's domestically focused, done through government spending. Now there are many countries collaborating in their infrastructure development. It's certainly multi modal and covers transportation, energy, communications, and many other areas. It's not just publicly financed either - yes, Chinese public funding has provided a jolt of support to Belt \& Road initiative - but it is multilateral as it is beginning to include the world's biggest financiers who are seeking to tap into this initiative. This includes both private financiers and other multilateral development banks (Khanna P., 2019).

The initiatives Silk Road (One Belt) and Maritime Silk Road (One Road) strive for the same win-win situation, achievable by building together, with the respect of common principles and the connection of three continents. The route is thought of as an economic tool which would stimulate growth and modernize ports as well as the infrastructure of the participating countries. The initiative has no political or military aims; on the contrary, which is always emphasized is the implementation of a peaceful plan, addressed towards China's wealth and the progress of the world.

The program is based on a win-win approach, on the five principles of a peaceful coexistence contained in the UN Charter: mutual respect, equality, fulfillment of the promise, mutual benefit, and a win-win approach.

"Belt and Road" is made of two parts (showed in Figure 5):

- the land "belt" that connects China to Central Asia, Russia, South Asia and Europe, and

- $\quad$ the maritime "belt" that connects Chinese ports to the ones in Southeast Asia, South Asia, Africa, the Middle East, and Europe.

The goal of the initiative "Belt and Road" is to connect Asia, Europe, and Africa through five transport routes.

The land belt focuses on: (1) connecting China with Europe through Central Asia and Russia; (2) connecting China with the Near East through Central Asia; (3) connecting China and Southeast Asia, South Asia and the Indian Ocean. The maritime "road" focuses on using Chinese coastal ports: (4) connecting China with Europe through the South China Sea and the Indian Ocean; and (5) connecting China with the South Pacific Ocean through the South China Sea. (Wong B., 2016).

By targeting the above indicated five routes, the $21 \mathrm{st}$ century Silk Road ("Belt and Road"), will use the advantages of international transport routes as well as the key cities and ports to additionally strengthen cooperation and build six international economic cooperation corridors.

The initiative "Belt and Road" has been identified as the

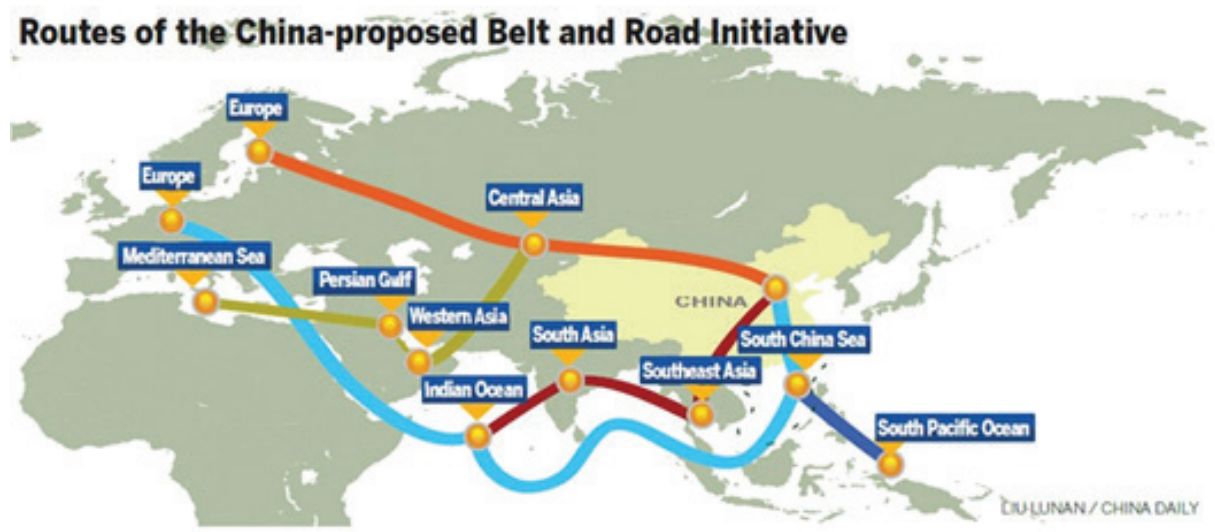

Figure 5.

The Chinese route for the initiative "Belt and Road" (China Daily, 2015). 
New Land Bridge in Eurasia, China-Mongolia-Russia, ChinaCentral Asia-Western Asia, the peninsula of China-Indochina, China-Pakistan and Bangladesh-China-India-Myanmar (Wong B., 2016).

The transit route from Yokohama to Hamburg through the Northern Sea Route is 6,600 nautical miles distant, while the one through the Suez Canal counts 11,400 nautical miles. From this, it can be concluded that through the Northern Sea Route the voyage from Japan to Europe would be reduced by 40 percent. Following the above mentioned, it may be suggested that the Northern Sea Route will provide China with a faster freight consignment in Europe and reduce the transit time by 20 to $30 \%$, which will save a significant amount of fuel and human resources. Considering that $90 \%$ of the Chinese goods are delivered by sea, the development of the Polar Silk Road could potentially ensure for China a major economic growth, but also an increase in the profit (Babić N., 2018).

\subsection{Affirmation of Reference Ports}

Ports represent the origin of the worldwide navigation, i.e. significant hubs in the circulation of maritime freight flows. They connect individual maritime routes and, together with them, create a network of formed routes. Taking into account the very the fact that ports are reference points in which it is possible to measure the intensity, i.e. the volume of freight flows, port traffic (ports of departure-destination) is an indicator of the quantity of maritime traffic in individual maritime routes (Poletan Jugović T., 2014.).

Reference transport hubs, i.e. ports on the Northern Sea Route are: Murmansk, Arhangelsk, Nordvik, Ambarčik, Igarka, Dudinka, Dikson, Tiksi, Pevek, Providenije, whose traffic (the number of vessel arrivals/departures) in 2017 is shown in the following figure.

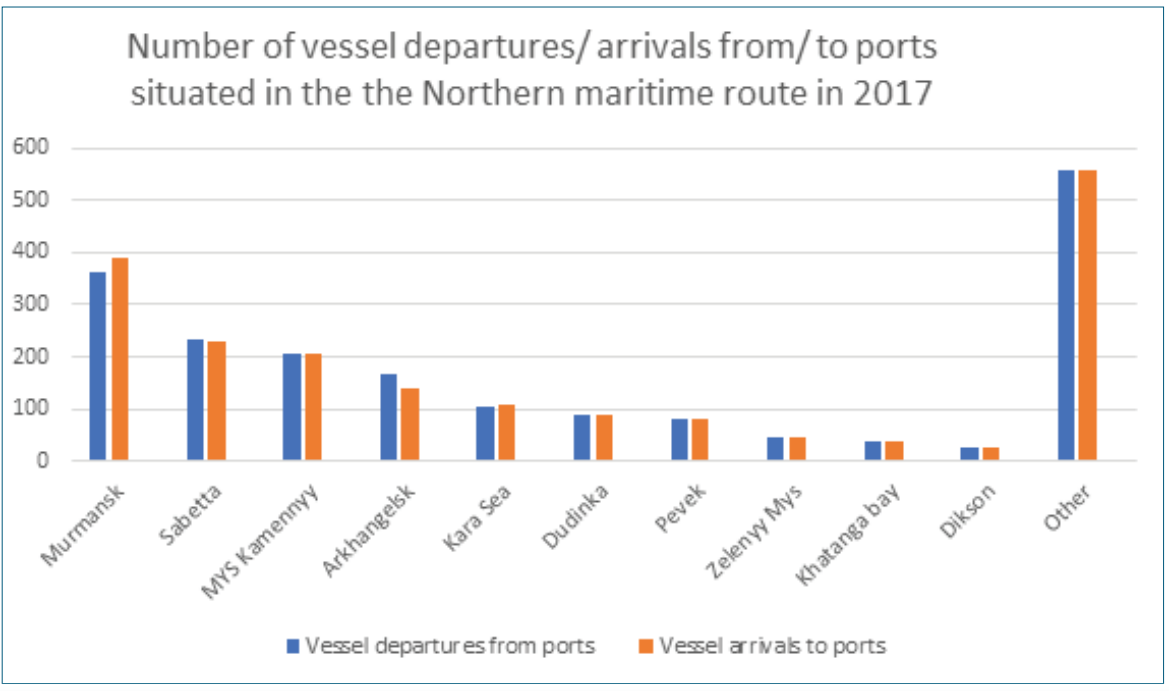

Figure 6.

Number of vessel departures/ arrivals from/to ports situated in the Northern Sea Route in 2017 (Centre for High North Logistic, 2018).

Based on the elaborated data from the port of Murmansk, with 363 departures from the port and 390 arrivals to the port in 2017, this is the most frequent Russian port in 2017, and with the affirmation of the Northern Sea Route, the above mentioned port traffic is likely to increase, especially because of its location on the most significant courses of the Northern Sea Route, as shown in Figure 5. An increase in the number of arrivals and departures from/to the Northern route ports indicates the need to invest in the ports mentioned.

For the Northern Sea Route to realize its full potential also as a transit route, a number of changes need to take place in the coming years and decades to improve the route's overall safety, reliability, services, and attractiveness for shipowners and cargo owners. A further development of essential transportation and logistics infrastructure is needed, including more icebreakers to assist vessels, a fleet of specialized high ice-class Arctic shuttles, improved search and rescue capacity, oil spill preparedness and response, environmental protection measures, communication systems, hydrographic surveying and navigational aids, and better forecasting of sea-ice conditions. These measures together with the modernization of Russian Arctic ports will take time and will require large investments (Centre for High North Logistic, 2019).

With the document "Strategic goals and recommendations for the EU's maritime transport policy until 2018", the European Commission has confirmed to the European Parliament that 
with the increase and expansion of the maritime routes capacity, part of the traffic will inevitably be attracted to the Northern Sea Route, which has "special requests". The European Commission estimates that it is in Europe's interest to research and improve the conditions that would gradually lead to joint navigation in the Arctic. The EU (as well as the USA) considers that it is important to emphasize that all the member states should support the principle according to which the right of undisturbed passage and the freedom of navigation would be allowed on the newly opened routes and passages.

The Ilulissat Declaration from May 2008, which was issued by the Arctic coastal states (Canada, Denmark-Greenland, Norway, Russia and the USA), has touched upon a sensitive topic related to sovereignty and jurisdiction of the Arctic coastal states in the greater area of the Arctic. In their opinion, it is not necessary to adopt any new legal regime in that area. In this way, the declaration has left the impression that it excludes not only non-Arctic states, but also Finland, Sweden and Iceland, which are also members of the Arctic Circle Assembly. The European Commission has demonstrated its interest for a greater role in the Arctic region and it encourages challenges in the Arctic to become an international issue. However, the Arctic Circle Assembly still keeps on hold the EU's application to join the Assembly in the role of observer, while China has entered this selected circle in 2013, together with India, Italy, Japan, South Korea and Singapore (Blunden M., 2012).

Before the above mentioned countries, the role of the observer has also been approved to France, Germany, the Netherlands, Poland, Spain, and the United Kingdom. The refusal to grant the observer status to $E U$ is to be found in the disagreement with the European seal hunt ban. Germany sees the Ilulissat declaration as an attempt to isolate Arctic regions from the influence of other interested parties, and it considers that the five above mentioned Arctic states emphasize their supremacy over that area, which is the reason why it will not be possible to influence issues related to the Arctic from the outside. Germany is aware that the Northern Sea Route can bring a considerable profit which is estimated, for large vessels, to half a million euros per voyage. Consultants in Germany consider that the Arctic resources should be declared world heritage sites, with the aim to look at everyone's well-being, which Russia opposes (Blunden M., 2012).

The signature of Italy's Accession Memorandum to the new Silk Road, will positively affect the development of the North Adriatic ports: Trieste, Koper, Rijeka, Venice and Ravenna. In case all the announced Chinese investments in Trieste and its transport route should be realized, which is still uncertain, the port of Trieste would not become a new Hong Kong or Singapore, especially not overnight. In other words, even with major investments, the port of Trieste is not sufficiently large to compete with the biggest and most important ports of Northern Europe in the matter of port infrastructure as well as in relation to the traffic connection and possibility to transport freights to the final destinations in due time (Glavan M., 2019).

For instance, as far as the container transport is concerned, which carries the greatest portion of goods between the Far East and the European market, all three ports, i.e. Trieste, Koper, and Rijeka, recorded top results last year. With 988,000 TEU, Koper approached its maximum current capacity; Trieste registered 625,000 TEU, and Rijeka 227,000. Altogether, the three ports did not have more than 2 million containers, which is less than $1 / 5$ of last year's container transport only in the port of Antwerp, where more than 10.5 million TEU have been transshipped. If we add the traffic of the port of Rotterdam (11 million TEU), of the port of Hamburg (10 million TEU) and others to the port of Antwerp, it is completely clear that the ports of Trieste, Koper and Rijeka altogether, even with major investments, could not compete with any of the above mentioned individual Northern European ports. Individually, they could not satisfy even roughly the needs of the Silk Road (Glavan M., 2019).

Finally, it can be concluded that the affirmation of the Northern Sea Route on the world stage will significantly influence the restructuring of freight flows at the world and European levels, but the influence on the North Adriatic ports cannot be certainly predicted, regardless of the signature of Italy's Accession Memorandum to the Silk Road.

\section{CONCLUSION}

New climate conditions are opening the possibility for international maritime navigation in the Arctic area, in particular through the Northern maritime route, as an incomparably shorter route between Asia and Europe than the one passing through the Suez Canal. Apart from natural limitations, the challenges of navigation on the Northern Sea Route are also represented by various other factors such as investments in the transport infrastructure and other requirements for a quality and safe service, as well as the consolidation of political-economic interests.

The Russian government promotes navigation through that route, but wants to keep its exclusive right of jurisdiction in the area. Although major tensions have not occured so far in relation to this matter, some countries disagree with this, considering that the route should be treated as a common world good and interest. The economic-political groups that, together with Russia, could affect the realization and the affirmation of this transport route are China and Japan, who are also interested to invest in the indicated route. In particular, China and Japan wish to invest in transport routes towards Europe, i.e. there is a potential opportunity to connect the Chinese project "One Belt, One Road" 
to the Northern Sea Route. It can be concluded that through the Northern Sea Route, the voyage from Japan to Europe would be reduced by $40 \%$. Following the above mentioned, it can be suggested that the Northern Sea Route will provide China with a faster freight consignment in Europe and reduction in the transit time by $20 \%-30 \%$, which will save a significant amount of fuel and human resources. Considering that $90 \%$ of the Chinese goods are delivered by sea, the development of the Polar Silk Road could potentially ensure not only a major economic growth for China, but also an increase in the profit.

Based on the main problem and object of research in this paper related to market analysis and affirmation factors of the Northern Sea Route, the research has made the following contribution:

- The most intensive traffic route is the one from/to the Northern Russian ports towards the Eastern (European) ports and Western (Russian and Asian) ports. With regard to the total number of voyages in 2017 , this route has registered $34 \%$ of all voyages.

- Immediately after this route, and based on intensity, i.e. the number of voyages, we can find the routes between Russian ports, with a $30 \%$ involvement, and the routes within the area of Western (European) Russia, with a 28\% involvement.

- The routes from European ports, including part of the routes towards European ports through the Suez Canal, have also been actualized, which suggests that a certain amount of freight circulating through the Northern Sea Route travels from the Suez Canal, a route with which the Northern Sea Route can potentially compete. Part of the traffic routes that pass through the Northern Sea Route represent a transit for the needs of Asian and European ports. The Northern Sea Route can, therefore, be defined as a competitive market of crucial interest, as the most intense traffic route in the global maritime transport.

Taking into account the above mentioned politicaleconomic interests as a relative-variable factor in planning the valorization of the transport route, the basic aim and purpose of the research is to analyze the existing situation in the indicated route and the affirmation factors of the transport route in the maritime market, with the aim to define further perspectives of the Northern Sea Route.

Following all the above mentioned, the contribution of research in this paper is reflected in the determination of the principal market categories that predispose the transport route's competitiveness, i.e. transport supply, demand, and environment in which the transport route exists. The Northern Sea Route has been analyzed based on the traffic structure according to the type of freight and vessels, the traffic direction and intensity in single route directions, the traffic intensity in ports, as port reference hubs. Based on the performed analysis, conclusions were drawn about the basic market definitions of the Northern Sea Route. Finally, relevant affirmation factors of the transport route on the dynamic maritime market, which always shapes new requests, expectations, and opportunities, were emphasized.

\section{REFERENCES}

Arctic Bulk, 2013. Available at: http://www.arcticbulk.com

Babić N., 2018. Logično, Bosna i Hercegovina. Available at: https://www.logicno. com/

Blunden, M., 2012. Geopolitics and the Northern Sea Route. International Affairs, 88(1), pp. 115-129. Available at:

http://dx.doi.org/10.1111/j.1468-2346.2012.01060.x.

Centre for High North Logistic, 2018. Detailed analysis of ship traffic on the NSR in 2017 based on AIS data. Available at: http://arctic-lio.com/.

CentreforHigh North Logistic, 2019. MaritimeTrafficandTransportation Infrastructure along the Northern Sea Route. Available at: https://businessindexnorth.com.

Glavan M., 2019. Novilist. Available at: http://novilist.hr/index.php/layout/set/print/ Vijesti/Hrvatska/Zabrinute-i-Hrvatska-i-Slovenija-Put-svile-na-Jadranu-moguservisirati-samo-sve-luke-zajedno.

International maritime organization, IMO, 2019. Available at: http://www.imo.org.

Jugović, A., Hess, S. \& Poletan Jugović, T., 2012. Traffic Demand Forecasting for Port Services. PROMET - Traffic\&Transportation, 23(1), pp. 59-69. Available at: http://dx.doi.org/10.7307/ptt.v23i1.149.

Khanna P., 2019. The Future Is Asian. Simon \& Schuster, New York.

Koboević, Ž. et al., 2018. Pomorski put svile i kineska inicijativa „pojas i put“. Naše more, 65(2), pp. 113-122. Available at:

http://dx.doi.org/10.17818/nm/2018/2.7

Poletan Jugović T., 2014. Robni tokovi. Pomorski fakultet u Rijeci, Sveučilište u Rijeci, Rijeka.

Rodrique J.P., 2013. The Geography of Transport Systems,Third Edition. New York.

Strategic goals and recommendations for the EU's maritime transport policy until 2018, Europska komisija, COM (209), 2009., odlomak. 4.

Unknown at Express.hr, 2019. Available at: https://www.express.hr/ekonomix/ pakleni-plan-rusa-za-najopasniji-pomorski-put-12416.

Unknown at China dail, 2015. Available at: http://www.chinadaily.com.cn/ bizchina/2015-04/15/content_20435585.htm.

Unknown at Pomorac net, 2019. Available at: http://pomorac.net/2018/09/07/ sjeverni-pomorski-put-zbog-novih-pravila-najbolja-opcija-za-tranzitne-divove/.

Wong B., 2016. The Belt and Road Initiative. "HKTDC". Available at: http://chinatrade-research.hktdc.com. 